\title{
A releitura do passado farroupilha no IHGB (1921-1935): memória republicana e legitimidades intelectuais ${ }^{l}$
}

\author{
Mara Cristina de Matos Rodrigues[1]
}

\begin{abstract}
Resumo
O artigo trata da releitura da Guerra dos Farrapos (1835-1845) no IHGB, entre os anos 1920 e a comemoração do centenário do conflito, em 1935, que acabou por integrá-lo à memória histórica nacional. Neste processo, foram acionadas estratégias discursivas e institucionais, relacionadas ao uso político do passado, à tradição historiográfica do IHGB e às legitimidades intelectuais construídas.

Palavras-chave: memória farroupilha; historiografia brasileira; IHGB.

La relectura del pasado farroupilha en el IHGB (1921-1935): memoria republicana y legitimidades intelectuales
\end{abstract}

\section{Resumen}

El artículo trata de la relectura del passado farroupilha en el IHGB, entre los años 1920 y la conmemoración del centenario farroupilha, en 1935, que acabó por integrarlo a la memoria histórica nacional. En este proceso, fueron accionadas estrategias discursivas e institucionales, relacionadas al uso político del pasado, a la tradición historiográfica del IHGB y a las legitimidades intelectuales historicamente producidas. Palabras clave: memoria farroupilha; historiografía brasileña; IHGB.

Re-reading of the Farroupilha past at IHGB (1921-1935): Republican memory and intellectual legitimacies

\begin{abstract}
This paper addresses a re-reading of the Farroupilha War (1835-1845) at IHGB from the 1920's to the celebration of the conflict centenary in 1935, which ended up integrating it into the national historical memory. In this process, discursive and institutional strategies were triggered, regarding the political use of the past, the historiographical tradition of IHGB and the constructed intellectual legitimacies. Keywords: farroupilha memory; Brazilian historiography; IHGB.

\section{Relire du passé Farroupilha dans le IHGB (1921-1935): mémoire républicaine et légitimité intellectuelle}

Résumé

Cet article est une relire du passé Farroupilha dans le IHGB dans les années 1920 et la celebratión du centenaire de la revolutión Farroupilha dans 1935, qui a integré le evenement à la mémoire historique du pays. Dans ce processus, stratégies discursives et institutionnelles ont été chassés en ce qui concerne leur utilizatión dans la politique, la traditión historiographique du IHGB, et las légitimités intellectuelles produites historiquement.
\end{abstract}

Mots-clés: memoire farroupilha; historiographie brésilienne; IHGB.

Artigo recebido em 10 de janeiro de 2013 e aprovado para publicação em 17 de abril de 2013.

[1] Departamento de História da Universidade Federal do Rio Grande do Sul (UFRGS) - Porto Alegre (RS) - Brasil. E-mail: mara.rodrigues@ufrgs.br

'Este trabalho foi produzido como parte de um estágio de pós-doutoramento júnior realizado no Programa de Pós-Graduação em História na Universidade Federal Fluminense, com bolsa do CNPq, no ano de 2011, sob a supervisão da Professora Doutora Angela de Castro Gomes, a quem muito agradeço a leitura da primeira versão deste texto e a convivência frutífera nesse período. Expresso também minha gratidão a meus orientandos de Iniciação Científica, Gabriela Correa da Silva e Marcelo Scarparo, e de Mestrado, Juliano Antoniolli, que auxiliaram neste projeto. 
ano de 1935, que marca o final do período recortado neste artigo, já evidencia o resultado das escolhas sul-rio-grandenses no que diz respeito à sua inserção no quadro da memória histórica republicana no Instituto Histórico e Geográfico Brasileiro (IHGB): a Revolução Farroupilha, cujo centenário foi amplamente comemorado neste ano, ocupa, desde então, espaço privilegiado na memória do estado sulino e na articulação do mesmo com a memória nacional. ${ }^{2}$ Em vista das dificuldades evidentes colocadas pelo paradoxo da promoção de um evento no qual vigorou uma república separada do Império brasileiro como o melhor representante histórico da presença sul-rio-grandense na nação, a preocupação central deste artigo é compreender como esse processo se deu e quais foram os seus principais delineamentos no âmbito da produção historiográfica institucionalizada nos institutos históricos nacional e regional no primeiro terço do século XX.

O conjunto das fontes primárias analisadas neste trabalho é constituído pelas atas das sessões e artigos da Revista do Instituto Histórico e Geográfico Brasileiro (RIHGB) entre os anos de 1921 e 1935 cotejadas com atas e artigos da Revista do Instituto Histórico e Geográfico do Rio Grande do Sul (RIHGRS), bem como algumas obras produzidas fora do âmbito institucionalizado da escrita da história, recuando-se no tempo quando necessário, na medida em que o espaço de um artigo o permite fazer. Os critérios que definiram a periodização adotada neste trabalho devem muito a um importante marco na institucionalização da escrita da história no Rio Grande do Sul, que ocorreu de forma tardia em relação a outros estados da federação: a fundação do IHGRS, em 1920. Além disso, a articulação entre este recorte temporal e a delimitação das fontes primárias visa superar pelo menos duas tendências verificadas desde os anos 1980 nos estudos sobre a historiografia sul-rio-grandense, especialmente aquela ligada ao IHGRS: a primeira é a que, ao voltar os olhos quase exclusivamente para o quadro regional, acaba por minimizar ou mesmo negligenciar a articulação entre o regional e o

\footnotetext{
${ }^{2}$ Revolução Farroupilha foi o nome pelo qual se tornou conhecida a guerra civil que, entre os anos de 1835 e 1845, opôs senhores de terra e criadores de gado em várias partes da província do Rio Grande de São Pedro, localizada no extremo sul do Brasil, ao governo imperial brasileiro e seus representantes. Dentre as motivações do conflito, podem ser apontadas questões de ordem econômica, como a demanda dos criadores e charqueadores pela proteção do governo imperial da carne salgada produzida no sul em relação à que se importava do Uruguai a preços mais baixos. Agregavam-se a esse problema econômico motivações de ordem política, relacionadas ao processo de construção e centralização do estado nacional brasileiro em curso desde a independência do país, em 1822. Os rebeldes se autodenominavam "farrapos", termo que denominava um movimento liberal extremista originário da corte, em 1831. O movimento rebelde teve algum sucesso militar, pois além de alongar o conflito por quase dez anos, logrou estabelecer um governo republicano que proclamou sua autonomia do Império brasileiro. O conflito foi finalizado com um acordo de paz que reintegrou a província sulina ao Império brasileiro, bastante vantajoso aos chefes farrapos, mas extremamente prejudicial a muitos de seus escravos que haviam sido libertos durante a guerra. Sobre o assunto, ver Cesar A. B. Guazzelli, "Fronteiras em conflito no espaço platino: da Guerra dos Farrapos à Guerra Grande", In: Luiz A. Grijó; Eduardo Santos Neumann (orgs.), O continente em armas: uma história da guerra no sul do Brasil, Rio de Janeiro, Apicuri, 2010, p. 97-122; Moacyr Flores, Modelo político dos farrapos, 4. ed., Porto Alegre, Mercado Aberto, 1996, p. 13-25.
} 
nacional no que tange aos empreendimentos historiográficos e à construção da memória histórica. ${ }^{3}$ Pretendemos demonstrar que pelo menos uma parte dos intelectuais, tal como faziam os políticos, tinha sua atenção voltada para o contexto nacional da disputa pelo poder e da concorrência simbólica. A outra tendência foi a de limitar esse vínculo entre historiografia regional - especialmente aquela produzida sob o abrigo do IHGRS - e nacional no período estudado quase exclusivamente à legitimação das ambições políticas de Getúlio Vargas e seus apoiadores. ${ }^{4}$ Mesmo considerando que a condição histórica ${ }^{5}$ da historiografia nesse período impôs aos seus artífices, de forma particularmente constrangedora, o atendimento a determinadas demandas sociais e políticas, buscamos complexificar esse quadro por meio da análise das relações problemáticas entre a memória histórica regional e a tradição da escrita da história no IHGB. Para atingir esse objetivo, enfocamos as estratégias discursivas e institucionais dos membros do IHGB relacionadas ao estudo específico do passado sul-rio-grandense.

Do ponto de vista dos pressupostos teóricos que orientam este trabalho, passamos agora a explicitar algumas escolhas que já tornamos visíveis acima, desenvolvendo outras reflexões na medida em que se desenrolar a análise das fontes primárias. Em primeiro lugar, cabe apontar a inserção deste trabalho em uma abordagem que vem sendo definida como história da historiografia, entendendo esta como operação historiográfica nos termos propostos pela apropriação que Paul Ricoeur fez da noção proposta por Michel de Certeau. ${ }^{6}$ Segundo Ricoeur, para além das distinções entre a escrita da história e a fenomenologia da memória, existem relações indissociáveis entre ambas no que se refere a uma abordagem simultaneamente

\footnotetext{
${ }^{3}$ Dentre muitos trabalhos que poderiam ser citados como exemplares desta tendência de abordagem do IHGRS estão: Marlene M. de Almeida, Introdução ao Estudo da Historiografia Sul-rio-grandense: inovações e recorrências do discurso oficial (1920-1935), Dissertação, Porto Alegre, IFCH-UFRGS, 1983; Sandra Pesavento, "Historiografia e ideologia". In: J. Dacanal; S. Gonzaga (orgs.), RS: Cultura e Ideologia, Porto Alegre, Mercado Aberto, 1996 [1980], p. 60-88; e leda Gutfreind, A historiografia rio-grandense, 2. ed., Porto Alegre, UFRGS, 1998, embora essa autora tenha feito rápidas referências ao quadro da historiografia nacional no período. Mais recentemente, essa tendência pode ser observada na tese de doutorado da própria autora deste artigo: Mara C. M. Rodrigues, Da crítica à história: Moysés Vellinho e a trama entre a província e a nação 1925 a 1964, Tese, Porto Alegre, PPGH-UFRGS, 2006. Alguns trabalhos romperam com essa perspectiva, em geral, aqueles produzidos fora do Rio Grande do Sul: Alexandre Lazzari, Entre a grande e a pequena pátria: literatos, identidade gaúcha e nacionalidade (1860-1910), Tese, Campinas, IFCHUnicamp, 2004, Letícia B. Nedel, Um passado novo para uma história em crise: regionalistas e folcloristas no Rio Grande do Sul (1948-1965), Tese, PPGH/ICH-UnB, 2005.

${ }^{4}$ Aqui podem ser lembrados novamente leda Gutfreind, op cit. e Marlene M. de Almeida, op cit.

${ }^{5} \mathrm{~A}$ reflexão sobre a condição histórica da escrita da história, desenvolvida na terceira parte da obra de Paul Ricoeur, A memória, a história, o esquecimento, Campinas, Ed. Unicamp, 2007, foi motivada por algo que também nos preocupa neste artigo: aquilo que o autor qualifica como "justa memória”, ou seja, uma prática social equilibrada entre os excessos de memória e de esquecimento.

\%/dem, Ibidem; Michel de Certeau, A escrita da história, Tradução de Maria de Lourdes Menezes, 2. ed., Rio de Janeiro, Forense Universitária, 2002.
} 
cognitiva e pragmática. ${ }^{7}$ Sendo assim, essa dupla abordagem nos permite trabalhar com a articulação entre essas duas formas de representação do passado característica desse período. ${ }^{8}$

Neste artigo, a operação historiográfica será pensada particularmente do ponto de vista de sua relação inescapável com um determinado tempo e lugar, tendo em vista as relações problemáticas entre as diferentes memórias regionais no contexto de renegociação da memória nacional em prol de uma representação historiográfica mais adequada ao Brasil na crise político-simbólica entre os anos 1920 e 1930. Desenvolveremos nossa análise evidenciando também que, se por um lado, o horizonte de expectativa da historiografia nacional - marcado pelo espaço de experiência da crise do liberalismo político dos anos $1920^{9}$ - não autorizava abolir toda experiência historiográfica passada especialmente aquela que vinha empreendendo a releitura da história do Brasil em uma chave republicana,$-{ }^{10}$ por outro, a sua reinterpretação era exigida para atender às demandas simbólicas e materiais do momento. No âmbito de vigência de experiência temporal e conceito de história modernos, as transformações mais contundentes do tempo presente abrem um novo futuro e requerem, desta forma, um novo passado.

\section{Rompendo o silêncio: as disputas em torno da noção de República}

Dentre as matérias mais importantes sobre a história da então província sulina aparecidas na revista do IHGB, está a "Guerra Civil do Rio Grande do

\footnotetext{
7Paul Ricoeur, "L'écriture de l'histoire et la representation du passe", Annales HSS, jul-ago. 2000, n. 4, p. 731743. Para o autor, a história compartilha com a memória as mesmas dificuldades cognitivas e pragmáticas concernentes à representação do passado: a aporia da presença em imagem de uma coisa ausente e os obstáculos que dificultam a fidelidade da memória ou a verdade da história: a memória impedida, manipulada e obrigada. Segundo Rüsen, a cultura histórica tem uma tripla dimensão, estética, política e cognitiva. Nas páginas a seguir, preocupamo-nos sobretudo com a dimensão política da historiografia, isto é, com a vinculação entre os historiadores e a produção da memória histórica acionada para a constituição de legitimidades políticas. Jörn Rüsen, Qué es la cultura histórica?: Reflexiones sobre una nueva manera de abordar la historia, Tradução de F. S. Costa e lb Schumacher, 1994. Disponível em: <http://www.culturahistorica. es/ruesen/cultura historica.pdf>, acesso em: 19 de julho de 2011.

${ }^{8}$ De forma complementar a essa reflexão, para tratar com a dimensão memorialística da operação historiográfica do início do século XX, destacamos a noção de memória histórica, diferenciando-a de memória coletiva. Essa distinção se opera fundamentalmente pela marca que os usos políticos conferem a esta prática de representação do passado, de acordo com a sua apropriação por grupos sociais, partidos, Estados ou Igrejas. Marie-Claire Lavabre, "De la notion de mémoire à la production des mémoires collectives", In: Daniel C'efaï (dir.), Cultures politiques, Paris, PUF, 2001, p. 233-252.

'Reinhart Koselleck, “Espaço de experiência e horizonte de expectativa: duas categorias históricas”, In: Futuro Passado, Tradução de Wilma Maas e Carlos Pereira, Rio de Janeiro, Contraponto, PUC-Rio, 2006, p. 305-328. ${ }^{10}$ Essa releitura da história nacional foi iniciada já no âmbito da propaganda republicana a partir das últimas décadas do século XIX, mas foi particularmente visível nas primeiras décadas do regime republicano, quando foram eleitos novos eventos e heróis como símbolos da nacionalidade. Sobre o assunto, ver, dentre outros, Lúcia Lippi Oliveira, "As festas que a República manda guardar", Estudos Históricos, vol. 2, n. 4, Rio de Janeiro, 1989, p. 172-189, José Murilo de Carvalho, "Tiradentes: um herói para a República", In: A formação das almas: o imaginário da República no Brasil, São Paulo, Cia das Letras, 1990, p. 55-73, Lúcia M. P. Guimarães, Da escola palatina ao silogeu: Instituto Histórico e Geográfico Brasileiro (1889-1938), Rio de Janeiro, Ed. Museu da República, 2006 e, mais recentemente, Angela Gomes; Marta Abreu, A nova “Velha” República: um pouco de história e historiografia", Revista Tempo, vol. 13, n. 26, Niterói, 2009, p. 1-15.
} 
Sul", memória de autoria de Tristão de Alencar Araripe, ${ }^{11}$ publicada em quatro partes, sendo a primeira, em 1880. ${ }^{12}$ Após um longo silêncio sobre assunto tão controvertido, a revista finalmente publicava uma versão cientificamente autorizada sobre a Guerra dos Farrapos. Até então, nem mesmo dentre os sul-rio-grandenses a Revolução de 1835 se constituía como um objeto de história. Provavelmente, a presença de ex-combatentes de ambos os lados ou de seus descendentes diretos na elite política sul-rio-grandense em postos de poder político e militar representasse, tanto no cenário local quanto na instituição nacional, um empecilho para a elaboração de uma representação bem aceita daquele conflito passado. No Rio Grande do Sul, dentre as primeiras tentativas de se escrever sobre aquele evento político-militar, estão as de membros do Partenon Literário, uma organização cultural cujo principal objetivo era desenvolver as práticas literárias na província, incipientes naquele último terço do século XIX. ${ }^{13} \mathrm{O}$ Instituto Histórico e Geográfico da Província de São Pedro (IHGPSP), fundado em 1860, mas de curta duração, não chegou a tocar no assunto, embora alguns de seus membros o fizessem fora da instituição, especialmente no âmbito das discussões político-partidárias. ${ }^{14}$

O fato é que o artigo - depois livro - de Araripe causou um enorme impacto no meio político local, em pleno contexto da agitação republicana, impulsionando a escrita de artigos e de outros livros que buscavam se constituir em contraponto ao que escrevera o ex-governador da província sulina. No seio dessa discussão, surge uma das obras mais conhecidas sobre a Revolução Farroupilha: A república rio-grandense, de João Francisco

"O conselheiro Tristão de Alencar Araripe era cearense, oriundo de uma família de larga tradição política, que atuou nas revoluções de 1817 e 1824. Foi magistrado e exerceu vários cargos políticos no Império, dentre eles, o de governador do Rio Grande do Sul nos anos de 1876 e 1877, em meio à ascensão da propaganda republicana no estado, como lembra em seu necrológio o então orador do IHGB, Afonso Celso. Foi sócio benemérito do IHGB e seu filho, Araripe Júnior, também foi destacado político e crítico literário, além de sócio do IHGB. RIHGB, t. 71, vol. 118, 1908, p. 607-608.

${ }^{12}$ A "Guerra Civil do Rio Grande do Sul. Memória acompanhada de documentos, lida no Instituto Histórico e Geográfico do Brasil" foi publicada nas seguintes revistas do IHGB: RIHGB, t. 43, vol. 61, 1880; t. 45, vol. 65, 1882; t. 46, vol. 67, 1883; e t. 47, vol. 69, 1884. As três últimas partes constituíram-se somente da transcrição de documentos relativos ao conflito.

${ }^{13}$ Antes de 1868, há pelo menos dois relatos de militares que participaram do conflito, pelo lado do Império. Eduardo Scheidt, "O processo de construção da memória da Revolução Farroupilha", Revista de História, v. 147, São Paulo, 2002, p. 189-209. Sobre o Partenon Literário, ver Alexandre Lazzari, Entre a grande e a pequena pátria: literatos, identidade gaúcha e nacionalidade (1860-1910), Tese, Campinas, IFCH-Unicamp, 2004; Cássia D. M. da Silveira, Dois pra lá, dois pra cá: o Parthenon Literário e as trocas entre a literatura e política na Porto Alegre do século XIX, Dissertação, Porto Alegre, PPGH-UFRGS, 2008 e Luciana F. Boeira, Entre a história e a literatura: a formação do panteão rio-grandense e os primórdios da escrita da história do Rio Grande do Sul no século XIX, Dissertação, Porto Alegre, PPGH - UFRGS, 2009.

${ }^{14}$ Alexandre Lazzari, op cit. p. 207. É na literatura que se realiza a vontade de romper o silêncio sobre a guerra civil. Segundo Boeira, embora a revista do Instituto Histórico e Geográfico da Província de São Pedro, publicada entre 1860 e 1863, não tenha registrado histórias ou memórias sobre o evento, estampou alguns documentos produzidos pelos rebeldes. Luciana Fernandes Boeira, Como salvar do esquecimento os atos bravos do passado rio-grandense: a Província de São Pedro como um problema político-historiográfico no Brasil Imperial. Qualif. Dout. Porto Alegre, PPGH, UFRGS, 2011 (mimeo). Sobre a memória farroupilha com tema da literatura no século XIX, ver também Sandra Pesavento, "Uma certa Revolução Farroupilha”. In: Keila Grinberg; Ricardo Salles (orgs.), O Brasil Imperial. Vol II - 1831-1870, Rio de Janeiro, Civilização Brasileira, 2009, p. 233-267. 
de Assis Brasil, ${ }^{15}$ que se opunha à versão "legalista" de Araripe. ${ }^{16}$ Essa obra teve ampla circulação, inclusive fora do Rio Grande do Sul, e marcou decisivamente o que se pensou e escreveu sobre a Revolução Farroupilha nas décadas seguintes. ${ }^{17}$

A compreensão dessa primeira polêmica sobre a Revolução Farroupilha é importante para que se possa avançar na análise da operação de releitura e reabilitação do passado farroupilha no início do século XX. Antes de entrar, contudo, na exposição sobre as teses defendidas pelos autores, é importante que se saliente que, desde esse momento precoce da construção da memória histórica farroupilha, os sul-rio-grandenses envolvidos no seu enquadramento tiveram atenção especial voltada ao que se pensava e dizia fora do Rio Grande do Sul em termos de modelos políticos e da memória nacional. ${ }^{18}$ Assis Brasil não se reportava exclusivamente às disputas políticas locais, embora estas, evidentemente, desempenhassem importante papel para aqueles homens tão devotados na reiterada busca da autonomia administrativa do estado. Entretanto, por maior que fosse a luta em torno do federalismo nesses anos finais do Império e mesmo que fosse esse o modelo eleito para a distribuição do poder político nacional no período subsequente à proclamação da República, as reivindicações de autonomia eram feitas com um olho nos interesses propriamente locais e outro atento às questões mais candentes no cenário nacional. Com a escrita da história não seria diferente.

O texto de Araripe, para começar, nomeava desde seu título a luta armada entre farroupilhas e imperiais como uma "guerra civil" e não como uma "revolução". Entretanto, não se trata de uma rejeição completa do sentido da palavra revolução para designar o conflito, pois a categoria é utilizada no corpo do texto: "a revolução começou sob a forma de uma sedição, vacilou sobre o seu procedimento, até que em novembro de 1836 tomou o caráter de uma rebelião, e proclamou a república". ${ }^{19}$ Além da preferência dada à noção de "guerra civil" em detrimento à de "revolução", o autor afirmava que a guerra civil, do lado dos revoltosos, fora capitaneada por caudilhos ${ }^{20}$ volta-

\footnotetext{
${ }^{15}$ João Francisco de Assis Brasil foi integrante da geração republicana de sul-rio-grandenses que estudou na Faculdade de Direito de São Paulo. Sobre os demais integrantes do grupo dos "federalistas positivistas gaúchos" e as ideias que defendiam na década de 1870, ver Ângela Alonso, Ideias em movimento: a geração 1870 na crise do Brasil-Império, São Paulo, Paz e Terra, 2002, p. 155-159.

${ }^{16}$ Joaquim Francisco de Assis Brasil, História da República Rio-Grandense. Porto Alegre, Cia União de Seguros Gerais, 1982 [1881], ERUS (Estante Rio-Grandense União de Seguros).

${ }^{17}$ Sobre a circulação da obra de Assis Brasil, ver Alexandre Lazzari, Entre a grande e a pequena pátria: literatos, identidade gaúcha e nacionalidade (1860-1910), Tese, Campinas, IFCH-Unicamp, 2004, p. 222 et seq. Mais do que essa obra e antes dela, A República federal, do mesmo autor, também teve ampla circulação. Maria Tereza C. de Mello, “A modernidade republicana”, Revista Tempo, n. 26, Niterói, UFF, 2009, p. 15-31. Ver p. 16.

${ }^{18} \mathrm{~A}$ noção de "enquadramento da memória" pressupõe que a memória não é construída arbitrariamente: ela se alimenta das produções herdadas da história. Michael Pollak, "Memória, esquecimento, silêncio", Estudos Históricos, vol. 2, n. 3, Rio de Janeiro, 1989, p. 3-15.

${ }^{19}$ R/HGB, t. 43, vol. 61, 1880, p. 155-116.

${ }^{20}$ Esta palavra em português tem o mesmo significado do termo espanhol caudillo, que designa um tipo de chefe militar recorrente na América do Sul, durante o século XIX, cujo poderio competia com os poderes politicamente centralizados.
} 
dos, acima de tudo, para seus interesses particulares em prejuízo dos interesses da nação. Desta forma, Araripe atingia em cheio um dos principais argumentos acionados na propaganda republicana, sobretudo a partir do grupo de estudantes da faculdade de Direito de São Paulo que integrava o Clube Vinte de Setembro. O antigo membro do IHGB, ex-governador da província, interpunha um enorme obstáculo aos que pretendiam legitimar as lutas do presente nas pretensões e realizações dos heróis do passado.

A filiação de Araripe a um ex-líder da Confederação do Equador parecia ser um importante suporte para autorizá-lo a negar o caráter republicano do movimento dos farrapos e a enfraquecer sua dimensão revolucionária, atributos reconhecidos pelo autor na Confederação tentada pelos pernambucanos e cearenses. Conforme o autor, estes teriam sido verdadeiros republicanos por priorizarem a causa da democracia, enquanto os farrapos teriam usado desse ideal para melhor defender seus objetivos privados, em um regime que ele denominava "despotismo militar". ${ }^{21}$ Nessa ótica, a luta pela república, quando identificada com a democracia, era legítima, mas esta não se aplicava ao caso da rebeldia dos líderes sul-rio-grandenses, que agiam em detrimento dos interesses coletivos. O conflito entre os

\section{A luta pela república, quando identificada com a democracia, era legítima, mas esta não se aplicava ao caso da rebeldia dos líderes sul-rio-grandenses}

farroupilhas e o Império, para o autor, representava antes o reverso do que o modelo de um movimento republicano. Entretanto, se na perspectiva de Araripe a luta ideológica (republicana) não podia ser invocada como argumento favorável aos chefes dos farrapos, o autor não chegou a acusá-los de separatismo, destacando que, se fosse essa a sua intenção, teriam como primeira atitude, após a proclamação da República Piratini, a aproximação com as repúblicas vizinhas, o que não foi feito. ${ }^{22}$

Assis Brasil escreveu sua versão sobre a Revolução Farroupilha logo após a publicação do livro de Araripe, por atribuição do Clube Vinte de Setembro, da Faculdade de Direito de São Paulo. O próprio nome do clube que reunia os estudantes republicanos evidencia que, a despeito do silêncio historiográfico, no plano político, o uso do passado farroupilha constituía-se como arma

21R/HGB, t. 43, vol. 61, 1880, p. 118

22/dem, Ibidem, p. 121. 
ideológica. ${ }^{23} \mathrm{O}$ autor iniciava seu livro fazendo referência a essa incumbência e ao pouco tempo de que dispusera para dar conta da mesma. Revelava grande admiração ao livro de Araripe confessando que a ele se devia a inspiração para sua obra, conquanto manifestasse "fundamental discordância" com suas ideias e mesmo com alguns fatos por ele narrados. ${ }^{24}$

Uma das diferenças fundamentais entre as teses dos dois autores acha-se nas causas apresentadas para a "revolução". Para Araripe, como visto, o que movera o conflito foram prioritariamente os interesses privados dos caudilhos sul-rio-grandenses, enquanto, para Assis Brasil, a revolução foi decorrência natural da contradição que existia entre as instituições centralizadas no governo imperial e a natureza e caráter do povo da província. Um país de tamanhas dimensões, como as do Brasil, não poderia ser governado pelas mesmas instituições e regras de norte a sul. Assis Brasil não deixava, entretanto, de apontar as proximidades entre o sentimento de contrariedade que reinava no Rio Grande e aquele que também se verificava em outras províncias brasileiras em relação à uniformidade forçada pela política imperial na década de $1830 .{ }^{25}$ Apesar de enfatizar as diferenças que justificariam a autonomia das províncias, reivindicada pelos defensores do federalismo, em livro anterior, já tinha pensado os limites dessa distinção dos sul-rio-grandenses em relação aos brasileiros, que não necessariamente os tornava platinos. ${ }^{26}$

Quanto à presença de um ideário republicano, o autor afirmava que, antes de Tito Lívio Zambeccari, um dos italianos que lutaram ao lado dos farrapos, não houve quem propugnasse pela República. Para Assis Brasil, ele fora o "diretor mental" da revolução, o que significava colocar as origens do republicanismo farroupilha na Europa e não nas repúblicas platinas. Ao mesmo tempo, a ideia de revolução já existia fora do Rio Grande e Bento Gonçalves a adotara no Rio de Janeiro, junto a homens como Evaristo da Veiga ${ }^{27}$ Desta forma, nesta rápida análise dos textos de Araripe e Assis Brasil sobre o conflito entre farrapos e Império, avulta a associação estreita entre os conceitos de revolução e

\footnotetext{
${ }^{23}$ Para Koselleck, uma das características associadas à emergência de conceitos políticos e sociais modernos é a sua ideologização, seu uso como fator, ou seja, como arma política e forma de produzir comportamentos. Sob essa perspectiva, não é propriamente a noção de revolução que se encontra em processo de modernização, mas sim a noção de república, cujos sentidos são disputados pelas duas versões historiográficas da revolução farroupilha. Koselleck, "Espaço de experiência e horizonte de expectativa: duas categorias históricas", In: ___.. Futuro Passado, Tradução de Wilma Maas e Carlos Pereira, Rio de Janeiro, Contraponto, PUC-Rio, 2006, p. 102.

${ }^{24}$ Assis Brasil, História da República Rio-Grandense. Porto Alegre, Cia União de Seguros Gerais, 1982 [1881], ERUS (Estante Rio-Grandense União de Seguros), p. IX. Conforme Lazzari, o Clube Vinte de Setembro, integrado por Julio de Castilhos, Joaquim Francisco de Assis Brasil, Homero Baptista (futuro membro do IHGB), entre outros, enviou correspondências a vários intelectuais, ex-combatentes e outros que pudessem deter informações, documentos e depoimentos valiosos para "corrigir as distorções" operadas por Araripe. Alexandre Lazzari, Entre a grande e a pequena pátria: literatos, identidade gaúcha e nacionalidade (18601910), Tese, Campinas, IFCH-Unicamp, 2004, p. 216-217.

${ }^{25}$ Assis Brasil, op cit., p. 52-53.

${ }^{26}$ Conforme Lazzari, referindo-se ao livro A República Federal, de Assis Brasil. Lazzari, op cit., p. 222-223. "Platino" é palavra que se escreve da mesma forma em português e espanhol para designar as pessoas originárias da região do Rio da Prata, isto é, argentinos e uruguaios. Foi utilizada aqui para afirmar a pertinência dos sul-riograndenses ao Brasil, apesar de suas similaridades culturais com os países vizinhos.

${ }^{27}$ Assis Brasil, op cit., p. 56-58.
} 
república, em ambos os textos, como termos quase intercambiáveis. ${ }^{28}$ Contudo, se havia concordância nessa aproximação, por outro lado, para ambos, república e revolução explicavam o conflito farroupilha com sinais invertidos: de forma negativa para o primeiro e de forma positiva para o segundo. $O$ fato é que esses textos permaneceram como as principais referências sobre a Revolução Farroupilha durante décadas. No IHGB, a autoridade de Araripe sobre o assunto parecia se estender para além de sua morte, ocorrida em 1908, já que, até o ano de 1921, não se viu outro artigo ou conferência que contestasse de forma clara a sua versão, mesmo em plena emergência de uma nova memória brasileira após a proclamação da República. Esse novo período de silêncio seria quebrado no início dos anos 1920, quando a revolução se tornaria objeto de comemorações e debates até a década de 1930.

\section{De caudilhos a heróis: primeira reabilitação no Instituto Histórico e Geográfico Brasileiro e o sentido do patriotismo}

Apesar de não terem sido publicados na revista do IHGB textos de porte equivalente ao de Araripe sobre a Revolução Farroupilha, pelo menos até o seu centenário, em 1935, esse limbo no campo historiográfico não se aplica ao da construção da memória histórica sul-rio-grandense, especificamente a farroupilha. ${ }^{29} \mathrm{Se}$, no espaço das elaborações textuais mais eruditas e cientificamente legitimadas dos artigos da revista, a Guerra dos Farrapos não se fazia presente, era no âmbito das comemorações, das conferências publicadas nas atas do IHGB, que ela emergia como temática importante da memória nacional. Depois que a elite política sul-rio-grandense aparou suas arestas e "arrumou a casa", o Rio Grande do Sul se projetou nacionalmente enquanto força política e simbólica. ${ }^{30}$

\footnotetext{
${ }^{28^{\prime}}$ Nas décadas finais do Império, o vocábulo república expandiu seu campo semântico incorporando as ideias de liberdade, progresso, ciência, democracia, termos que apontavam, todos, para um futuro desejado". Mello, "A modernidade republicana", Revista Tempo, n. 26, Niterói, UFF, 2009, p. 16.

${ }^{29}$ No século XIX, o Rio Grande do Sul era a segunda província brasileira mais abordada nos artigos da Revista do IHGB. Luciana Boeira, Como salvar do esquecimento os atos bravos do passado rio-grandense: a Província de São Pedro como um problema político-historiográfico no Brasil Imperial. Tese de Doutorado, Universidade Federal do Rio Grande do Sul, Porto Alegre, 2013. Desta forma, comparando-se ao século precedente, era discreta a presença do estado como problema historiográfico no período que abordamos. O passado sul-rio-grandense foi objeto de três artigos entre 1914 e 1921: dois referentes às Missões Jesuíticas e um sobre a campanha da Guerra do Paraguai no Rio Grande do Sul. RIHGB, t. 77, v. 130, 1914, p. $51-66$ e p. 181-190 e /dem, t. 85, v. 139, 1919, p. 107-278.

${ }^{30} \mathrm{Em}$ 1921, representantes das duas principais forças políticas já somavam esforços no recém-fundado IHGRS, contra o esquecimento do passado glorioso do estado. Em 1923, ocorreu o último grande embate entre partidários e adversários do eterno governador Borges de Medeiros no Rio Grande do Sul. No desfecho da Revolução de 1923, abriu-se espaço para a aliança entre o PRR, partido de situação nos tempos republicanos, e o PL, de oposição, em torno do nome de Getúlio Vargas, em 1928. Sobre o assunto, dentre muitos outros títulos, ver Joseph Love, O regionalismo gaúcho e as origens da Revolução de 1930, São Paulo, Perspectiva, 1975 e "A república brasileira: federalismo e regionalismo (1889-1937)", In: Carlos Guilherme Mota (org.), Viagem incompleta: a experiência brasileira (1500-2000). A grande transação. 2. ed. São Paulo, Editora SENAC SP, 2000, p. 121-160; Luiz A. Grijó, "Entre a barbárie e a civilização: os conflitos armados no período republicano", In: Eduardo Santos Neumann; Luiz Alberto Grijó (orgs.), O continente em armas: uma história da guerra no sul do Brasil. Rio de Janeiro, Apicuri, 2010, p. 159-184.
} 
Não se quer pressupor com essa abordagem nem um amalgamento, nem uma oposição radical entre os empreendimentos da história e da memória histórica nacional neste momento. A princípio, como hipótese de trabalho, procura-se preservar a distinção entre a história, entendida como uma operação de teor mais crítico na reconstrução do passado, e a memória histórica marcada, como dissemos anteriormente, pelo uso político do passado. Sob essa ótica, as duas operações poderiam ter espaço na mesma instituição em momentos diferenciados. A memória histórica, cultuada de maneira mais ostensiva no espaço das efemérides, das conferências e dos atos cívicos, de cuja construção participavam os institutos históricos nacional e regional, teria como contrapeso ao seu apelo emocional e político a possibilidade de crítica embasada em critérios normativos da instituição.

Em uma perspectiva que busca incluir as estratégias do lugar social de produção da história, pensado aqui tanto na sua configuração institucional quanto na sua inserção político-social, como parte indissociável da operação historiográfica em um tempo e lugar, podemos refletir sobre o caráter do recrutamento dos "historiadores" rio-grandenses no IHGB. ${ }^{31}$ Antes de 1920, registramos a presença de apenas seis sul-rio-grandenses em um universo de 163

Mas se os chefes farrapos não tinham sido
verdadeiramente republicanos, nem separatistas,
o que levara o general Netto a proclamar
a República Piratini?

sócios do IHGB. ${ }^{32}$ No ano seguinte, em 1921, três membros do recém-criado instituto regional (IHGRS) ingressaram como sócios correspondentes na instituição nacional, sendo que dois deles eram padres jesuítas - um dos quais já havia colaborado com a revista do IHGB - e o outro era o tenente-coronel

\footnotetext{
${ }^{31}$ Como se pode ver adiante, algumas indicações para sócios tinham um caráter político mais marcado que outras, apesar de se atentar sempre ao cumprimento da formalidade estatutária que prescrevia a análise de uma obra do candidato por uma das comissões especializadas (de história, arqueologia e etnografia, ou geografia, por exemplo) e outra a cargo da comissão de admissão e sócios. Sobre o perfil dos historiadores do IHGB, Angela Gomes considera a sua condição imprecisa, objeto ainda de debate, na especificidade do contexto em que se verificava uma interseção dos campos intelectual e político no Brasil de fins do século XIX e início do XX. Angela de Castro Gomes, A República, a História e o IHGB, Belo Horizonte, Argumentum, 2009, p. 26.

${ }^{32}$ São eles, Homero Baptista, Arthur da Rocha Pinto, Rivadávia Corrêa, Almirante Arthur Índio do Brasil e Ramiz Galvão, todos radicados no Rio de Janeiro. Além desses, o Marechal Hermes, que era também presidente honorário por ter sido presidente da república. Dentre os 64 sócios correspondentes, categoria que expressa melhor o tipo de historiador que reside no seu estado e trata de assuntos da sua região, não há nenhum radicado no Rio Grande do Sul. Ver relação de sócios feita em 1920, na RIHGB, t. 84, v. 138, 1918, p. 703-711. Rivadávia Corrêa, que ainda aparecia na relação de 1919, não aparece mais na de 1920 por ter falecido entre a confecção das duas listagens. R/HGB, 1918, t. 83, v. 137, p. 598. Como se pode ver adiante, a natalidade no Rio Grande do Sul não os tornou obrigatoriamente "historiadores regionais".
} 
Emílio Fernandes de Souza Docca, orador na nova instituição regional. ${ }^{33}$ Se as candidaturas dos padres jesuítas parecem ter sido embasadas mais nos seus predicados e méritos científicos, a de Souza Docca parece ter obedecido a um critério misto, pois ele era reconhecido regionalmente antes pelo tom patriótico de sua atividade historiadora do que pelos seus dotes eruditos. ${ }^{34}$ Mesmo sendo numericamente discreta a presença de sócios do novo instituto no IHGB, já que somente Souza Docca teve participação efetiva na agremiação, evidencia-se uma articulação entre as duas instituições a partir da fundação do IHGRS, que pode ser observada na emergência de discussões relacionadas ao Rio Grande do Sul, na agenda da instituição nacional.

Acompanhando-se rapidamente as trajetórias dos sócios sul-rio-grandenses no interior do IHGB antes de 1921, pode-se dizer que algumas indicações não primavam pelo critério do merecimento intelectual. Os pareceres das comissões de história e de sócios do IHGB não deixam dúvida, por exemplo, sobre o caráter predominantemente político das indicações de Rivadávia Correa e Homero Baptista quando estes atuavam no governo do Marechal Hermes da Fonseca. ${ }^{35}$ Somente Arthur da Rocha Pinto e Ramiz Galvão é que tiveram as suas candidaturas justificadas, acima de tudo, pela sua produção intelectual. ${ }^{36}$ Dentre esses sócios, nenhum se identificava com a escrita de uma história ligada prioritariamente ao passado regional. Contudo, Homero Baptista fez uma conferência relacionada, ainda que de forma indireta, ao tema da Revolução Farroupilha,

33Além do tenente-coronel, os outros dois sócios eram os padres jesuítas Carlos Teschauer e João Batista Hafkemeyer. Dos três sócios ingressantes em 1921, somente Souza Docca assumiu sua vaga, no mesmo ano, chegando posteriormente a sócio efetivo da instituição. RIHGB, t. 87, vol. 141, 1920, p. 537 et seq.

${ }^{34} \mathrm{O}$ seu cargo de orador do IHGRS também parece ter obedecido a um critério mais político do que acadêmico. Mais do que ele, os padres jesuítas, o romancista Alcides Maya e o seu futuro contendor, Alfredo Varella, por exemplo, dispunham de um capital intelectual consolidado. Entretanto, é difícil enquadrar Souza Docca como um político-historiador, pois, apesar de confluir com versões historiográficas propensas a um uso oficial por parte dos governos do estado do Rio Grande do Sul e do Brasil, nunca ocupou postos políticos de destaque. Além disso, costumava se identificar primeiramente como soldado e depois como historiador, o que se verifica em dois de seus primeiros discursos nos institutos regional e nacional. RIHGRS, 30 trim., 1921, p. 57-67; RIHGB, t. 90, vol. 144, 1921, p. 825-836.

${ }^{35}$ Rivadávia Corrêa foi indicado, juntamente com outro ministro de Estado, a sócio honorário da instituição com uma explícita intenção política. Na sua indicação, se fez referência ao seu cargo de Ministro da Justiça e dos Negócios Interiores. Como méritos apontados para o seu ingresso na instituição não foram referendadas obras históricas de sua autoria, mas sim a sua atuação na recente Reforma do Ensino e os "notáveis serviços" que prestara ao Instituto, que o recomendavam à gratidão de seus membros. Homero Baptista ingressou como sócio correspondente no IHGB em 1911, mas foi a sua indicação a sócio honorário, em 1914, que teve marcado caráter político. A essas alturas, Baptista já era sócio efetivo, pois residia na capital federal por conta de suas atividades no governo do Marechal Hermes. A dupla justificativa apresentada na sua indicação a honorário refere-se aos "assinalados serviços" por ele prestados ao Instituto, tanto no desempenho de seu cargo social quanto como representante da nação. Esses serviços podiam ser desde obtenção de subvenções governamentais a viagens de estudos até auxílio para publicações da instituição. R/HGB, t. 75 , vol. 126, 1912, p. 240; Idem, t. 74, vol. 124, 1911, p. 519 e 545-46; Idem, t. 77, vol. 130, p. 511.

${ }^{36}$ Arthur da Rocha Pinto era magistrado e professor universitário no Rio de Janeiro e havia colaborado como convidado para um curso promovido pelo IHGB em 1915. Ramiz Galvão, apesar de ser sul-rio-grandense e invocar essa origem em suas oratórias, já fora completamente integrado ao meio de sociabilidade política e profissional da capital federal, desde os tempos da corte imperial. Seu último cargo no Império fora o de preceptor dos filhos da princesa Isabel. Antes disso, já havia ingressado como sócio efetivo no Instituto. Sua posição no IHGB, portanto, nada deve às relações político-partidárias ou simbólicas com Rio Grande do Sul. RIHGB, t. 78, vol. 132, 1915, p. 639, 671-2. Ele fazia parte, juntamente com Max Fleuiss e o Conde de Afonso Celso, da chamada "trindade do Silogeu", responsável pelo soerguimento do IHGB após a morte do Barão de Rio Branco, em 1912. Lúcia M. P. Guimarães, Da escola palatina ao silogeu: Instituto Histórico e Geográfico Brasileiro (1889-1938), Rio de Janeiro, Ed. Museu da República, 2006. 
publicada em 1918: "Revoluções brasileiras de 1817 a 1835". ${ }^{37}$ Baptista também fora membro do Clube Vinte de Setembro, que encomendara a Assis Brasil seu livro sobre a Revolução Farroupilha. No entanto, a despeito dessa proximidade entre os dois, a República Rio-grandense não se constituiu como fonte privilegiada para Baptista e sequer foi citada. A obra mencionada na conferência a respeito do movimento farroupilha foi outra, bem menos conhecida dentro e fora do estado sulino, de autoria de Alfredo Ferreira Rodrigues, intitulada A pacificação do Rio Grande do Sul. ${ }^{38}$ Para Baptista, a Revolução Farroupilha teria sido um movimento legítimo de reação às políticas governamentais, tal como outros do período da regência, e por isso a inclui na série de revoluções brasileiras que aconteceram entre 1817 e 1838, sem lhe conferir, entretanto, algum caráter privilegiado ou destacado em relação às demais. A noção de revolução aqui se identificava prioritariamente com a luta contra a monarquia, retomando-se o sentido intercambiável com a noção de república.

Foi Souza Docca que iniciou de forma mais explícita a operação de reabilitação das lideranças farroupilhas na memória histórica nacional. ${ }^{39}$ Apesar de não ter sido o primeiro sul-rio-grandense a ser lembrado para ingressar no IHGB em 1921, foi o mais atuante dos três que ingressaram nesse ano, chegando a sócio efetivo alguns anos depois. Sua candidatura teve o apoio de peso de Max Fleiuss, que, em um de seus relatórios anuais, fez referência explícita à obra do tenente-coronel sobre a Guerra do Paraguai. Os padres jesuítas que foram indicados como correspondentes em 1921, juntamente com Sousa Docca, apesar de aparentemente muito prestigiados pelo seu trabalho historiográfico, nunca chegaram a tomar posse. O tenente-coronel, talvez em função de sua maior mobilidade enquanto militar, estava no Rio de Janeiro, no dia 19 de setembro de 1921, quando tomou posse e proferiu o discurso de praxe. Apesar de a sua candidatura ter se baseado em obra sobre a Guerra do Paraguai, o tema do seu discurso de posse foi a Revolução Farroupilha, que completaria, no dia seguinte, 86 anos. ${ }^{40}$ Desta feita, sim, pode-se perceber uma clara diferenciação entre a versão proposta por Araripe na década de 1880 e a que foi construída por Docca já avançados 20 anos do século XX. Para começar, é necessário dizer que, em muitos aspectos, o texto de 1921 não se distancia completamente do

${ }^{37}$ RIHGB, t. 83, vol. 137, 1918, p. 340-349

${ }^{38}$ Ferreira também fora sócio correspondente do IHGB, tendo ingressado no início do período republicano. Dentre seus trabalhos avaliados pela comissão de história, estavam alguns esboços biográficos de chefes farrapos, como Davi Canabarro. Idem, t. 59, vol. 94, 1896, p. 243, 274.

${ }^{39}$ Tomo intencionalmente o termo "reabilitação", utilizado por Aurelio Porto, historiador contemporâneo de Souza Docca, também membro do IHGRS, em texto publicado na RIHGRS, 20 trim., 1934, p. 309-320: "Processos dos Farrapos: Reabilitação de Bento Gonçalves”. O texto se trata da publicação de documentos do século XIX que provariam a lealdade de Bento Gonçalves ao Império brasileiro às vésperas da Guerra Cisplatina.

${ }^{40} \mathrm{Em}$ levantamento preliminar, esta parece ser a primeira "comemoração" do aniversário da Revolução Farroupilha no IHGB. Não foi detectada nenhuma sessão comemorativa nos anos em que o aniversário completava um "número redondo", como em 1905 e em 1915, por exemplo, respectivamente nos 70 e 80 anos do conflito. Nas efemérides do Barão de Rio Branco, publicadas em 1917, ele faz referência ao 20 de setembro, como era de se esperar, mostrando-se discretamente favorável ao Império, sem, entretanto, demonstrar desaprovação aos revoltosos. RIHGB, t. 82, vol. 136, 1917, p 452-453. É importante que se diga que o tom de Afonso Celso, após a fala de S. Docca, também era de que o episódio servisse como lição, mas no sentido do que devia ser feito para evitar novos empreendimentos separatistas. Idem, t. 90, vol. 144, p. 837. 
de Araripe quanto à sequência dos fatos e ao caráter não republicano do movimento. Para Docca, assim como para Araripe, os líderes farrapos não eram separatistas, nem republicanos por princípio. As circunstâncias do conflito, para o primeiro, e os interesses privados dos caudilhos, para o segundo, os teriam levado à proclamação da República e à separação do Império. Desta forma, a principal diferença entre o autor sul-rio-grandense e o cearense dizia respeito ao caráter moral, ao patriotismo das lideranças farroupilhas. Neste momento, portanto, para Souza Docca, importava menos acentuar o caráter republicano do movimento do que limpar a imagem dos guerreiros sulinos, afastando deles a pecha de caudilhismo. As primeiras palavras do discurso de Souza Docca denunciam um certo cuidado, provavelmente explicado pela presença no IHGB de muitos membros que haviam sido próximos ou tinham mesmo participado do governo monárquico nos seus últimos anos. O historiador debutante no instituto nacional devia falar a um público de ex-monarquistas, mas também de figuras atuantes do regime republicano, entre eles, o seu conterrâneo Homero Baptista. ${ }^{41}$ Embora já avançado o processo de recomposição organizacional da prática e do discurso do IHGB ao novo regime, ${ }^{42}$ Docca ainda parece desconfortável com essa convivência contraditória. Sendo assim, opta por acentuar o patriotismo e as elevadas intenções dos líderes farroupilhas:

Sinto-me feliz de poder principiar, afirmando-vos que Bento Gonçalves, Bento Manuel, Canabarro e Netto nunca foram separatistas de coração. Não tiveram também ideias republicanas arraigadas. Isto em nada os diminui; porque os nossos maiores não devem ser venerados pelo simples fato de terem sido republicanos ou monarquistas, e sim porque souberam ser uma ou outra coisa, sendo, sempre, acima de tudo, Brasileiros. ${ }^{43}$

Seja pelo temor de melindrar sua audiência ou pela precariedade em que ainda se encontravam as pesquisas históricas sobre o assunto, o neófito buscou também justificar os grandes homens farroupilhas aproximando-os de outros reconhecidos nomes da história nacional, especialmente caros ao IHGB, como o Barão de Rio Branco e Joaquim Nabuco, monarquistas que tiveram postos importantes na diplomacia republicana. ${ }^{44}$

Mas se os chefes farrapos não tinham sido verdadeiramente republicanos, nem separatistas, o que levara o general Netto a proclamar a República Piratini? Como se explicavam as relações tão próximas entre os farroupilhas

\footnotetext{
${ }^{41}$ Conforme Lúcia Paschoal Guimarães, Da escola palatina ao silogeu: Instituto Histórico e Geográfico Brasileiro (1889-1938), Rio de Janeiro, Ed. Museu da República, 2006, uma das estratégias mais bem sucedidas para preservar a integridade financeira e a importância cultural do Instituto após a proclamação da República foi adotada pela diretoria encabeçada por Afonso Celso, Max Fleiuss e Ramiz Galvão, a partir de 1912, que passou a integrar expoentes dos governos republicanos no corpo de sócios do IHGB. Mais do que isso, o discurso da instituição e a memória nacional que ali se cultuava foram transformados para se adequar às demandas do novo regime, evitando-se cuidadosamente, contudo, macular a memória do imperador Pedro II, maior benfeitor da instituição.

42Ė o que afirma Angela Gomes sobre o IHGB no período em questão. Gomes, A República, a História e o IHGB, Belo Horizonte, Argumentum, 2009, p. 30.

${ }^{43}$ RIHGB, t. 90, vol. 144, 1921, p. 825.

${ }^{44} / d e m$, Ibidem, p. 827.
} 
e importantes caudilhos do Prata, como Lavalleja e Fructuoso Rivera? A despeito da volubilidade atribuída a Bento Gonçalves, a maior responsabilidade sobre as contradições do movimento recaiu sobre os agitadores republicanos e, secundariamente, sobre o povo. Para Docca, os primeiros teriam impulsionado a situação para o lado da República e da separação, já que sua ação "calou profundamente no espírito do povo, sempre predisposto para revoltas e arruaças, e em consequência disso pode-se dizer que quase todo o Rio Grande do Sul se levantou para a revolução, em vinte de setembro, como um só homem" ${ }^{45}$ Esses agitadores provinham sobretudo de outras províncias brasileiras e do estrangeiro. Eram os carbonários italianos, como Tito Lívio Zambeccari e Giuseppe Garibaldi, e outros insufladores provindos dos países platinos. Sendo assim, a República não seria resultado de uma força natural e irresistível, como afirmara Assis Brasil, mas obra de forças exteriores ao caráter da província, muitas vezes maliciosas.

Essa interpretação dos fatos seria revista por Souza Docca nos anos posteriores, seja por estar mais ambientado e menos receoso na imponente casa da história nacional, seja por ter aprofundado seu conhecimento sobre o processo dos farrapos ou ainda por ter percebido a necessidade de inserir o Rio Grande do Sul na memória republicana nacional. Entretanto, o que se tinha em 1921 era um sul-rio-grandense proclamando em conferência no IHGB que Bento Gonçalves era um chefe bem intencionado, mas volúvel e influenciável; ${ }^{46}$ que a República não era uma força atávica no Rio Grande, já que ela vingara por obra dos republicanos de outras províncias brasileiras e do estrangeiro que haviam trazido suas más influências aos farrapos; por fim, o povo gaúcho era afeito à violência e à desordem. Talvez a versão de Araripe, no conjunto, fosse menos desairosa aos sul-rio-grandenses do que essa. Salvavam-se, contudo, as quatro grandes lideranças farroupilhas — os dois Bentos, Canabarro e Netto - da pecha de caudilhismo e separatismo sendo-lhes atribuído o epíteto de "centauros", veiculado na literatura local desde o século XIX para caracterizar genericamente o povo sul-rio-grandense.${ }^{47}$ Contudo, de forma significativa, a herança gloriosa dos farrapos foi logo estendida àquele

\footnotetext{
${ }^{45}$ RIHGB, t. 90, vol. 144, 1921, p. 831.

${ }^{46}$ É importante frisar o papel ambíguo atribuído a Bento Gonçalves da Silva nesse momento, em que sua memória ainda não desfrutava do imenso prestígio que atingiria no contexto do centenário farroupilha e nos anos seguintes, até a atualidade, no Rio Grande do Sul. Neste sentido, as discussões registradas nas atas de sessões internas do IHGRS na época do centenário demonstram a consolidação da sua figura como o maior herói dos farrapos. Especialmente a sessão do dia 11 de abril de 1933 marca a hierarquização dos valores simbólicos em jogo. Nessa ocasião, foram escolhidas as efígies que deveriam ser cunhadas nas moedas comemorativas e seus respectivos valores. A moeda com a efígie de Bento Gonçalves era a de maior valor, seguida pela de Duque de Caxias. O mesmo não acontecia com os selos, pois o de maior valor era o que estampava o Duque de Caxias, ocupando Bento Gonçalves a 10a posição dentre 16 heróis e eventos marcantes da revolução. Entretanto, é de se questionar se o selo de Bento não seria daqueles que mais circulariam por seu preço mais acessível... RIHGRS, 40 trim., 1933, p. 295-297.

${ }^{47} \mathrm{O}$ epíteto já era utilizado pelos membros do Partenon Literário. Alexandre Lazzari, Entre a grande e a pequena pátria: literatos, identidade gaúcha e nacionalidade (1860-1910), Tese, Campinas, IFCH-Unicamp, 2004. No contexto mais amplo de ressemantização do gaúcho entre 1889 e 1935, a rejeição do caudilhismo como característica das práticas políticas do Rio Grande do Sul constituiu-se apenas como mais uma das estratégias associadas a esse processo. Letícia Borges Nedel, "Caudilhismo, não! O papel da história linear na composição mítica do gaúcho: 1880-1935”, Em tempo de histórias, n. 5, ano 5, Brasília, 2001, p. 79-105.
} 
que os representara em uma narrativa histórica. Após a conferência de Souza Docca, Ramiz Galvão, como orador do IHGB, fez a saudação de praxe encerrando-a da seguinte forma:

\begin{abstract}
Com estas palavras, ungidas de amor e frementes de entusiasmo, que fizeram o fecho da vossa bela oração aplaudida pelo Instituto, com essas mesmas eu quero terminar esta sincera saudação que em nome dele vos dirijo. Sois um valoroso irmão dos Centauros: haveis de ser aqui ao nosso lado, um valoroso, um extremo batalhador pela Verdade e pela Justiça da História. ${ }^{48}$
\end{abstract}

Os heróis do passado reviviam no historiador do presente. Os caudilhos eram reabilitados ao mesmo tempo em que os sul-rio-grandenses ingressavam na sua era historiográfica. A mediação de Souza Docca se via legitimada pela noção de patriotismo e pelo estabelecimento da continuidade entre o passado e presente.

\title{
Revolução, republicana, federalista, patriótica e brasileira: enquadramento e síntese do heterogêneo na memória farroupillha
}

Entre 1921 e 1932, a revista do IHGB não apresenta novas manifestações quanto à memória farroupilha. Mas há alguns aspectos a serem analisados no que se refere à memória sul-rio-grandense como um todo e ao seu principal representante no Instituto Nacional. Em 1927, Souza Docca realizou uma conferência sobre o centenário do combate de Santiago, da Guerra da Cisplatina. Entretanto, a votação e aprovação de um manifesto, encabeçado por notáveis do IHGB como Afonso Celso e Max Fleiuss, não assinado por Souza Docca, precede a sua fala. Os consócios do IHGB estavam de acordo com a tese de que o combate do Ituzaingó (ou do Passo do Rosário), liderado pelo Marquês de Barbacena durante a Guerra da Cisplatina, não havia sido "desairoso para a nação". Fleiuss introduz o processo de votação lembrando e reafirmando trabalhos anteriores de membros do IHGB, dentre eles, figuras de peso como o Barão de Rio Branco e o Conde de Afonso Celso, que consideravam a polêmica batalha honrosa para as armas brasileiras. Sendo assim, devia ser comemorada, resguardando-se o devido respeito à atual situação continental de paz entre os antigos adversários. ${ }^{49} \mathrm{O}$ fato é digno de nota porque, em 1923, na revista do IHGRS, Souza Docca havia tomado o partido de Bento Manoel Ribeiro - militar atuante em Ituizaingó e depois líder na Guerra dos Farrapos -, culpando o Marquês de Barbacena pelo suposto insucesso nessa batalha. ${ }^{50}$

O que interessa aqui não são tanto as versões dadas para aquela batalha que precedera o movimento farroupilha, mas a existência de arestas entre

${ }^{48}$ RIHGB, t. 90, vol. 144, 1921, p. 838

49/dem, t. 101, vol. 155, 1927, p. 140-141

${ }^{50}$ RIHGRS, n. 3/4, 1923, p. 557-579, em especial, p. 561-563. 
as memórias concorrentes. ${ }^{51}$ A releitura da posição do Rio Grande do Sul no calendário das efemérides e no panteão nacional exigia um enquadramento da memória: Souza Docca, nessa conferência realizada em 1927, silenciou qualquer referência à figura de Bento Manoel, a quem ardentemente defendera em 1923 de ataques vindos supostamente do filho de Barbacena. No plano simbólico, o IHGB fazia concessões às versões dignificantes das lideranças farroupilhas; entretanto, as releituras da memória nacional não poderiam contradizer certos elementos essenciais do patrimônio simbólico e da autoridade historiográfica construídos até aquele momento na instituição. Também aqui, mas de outra forma, o enquadramento da memória se associava à construção de legitimidades intelectuais: Souza Docca, historiador neófito, não tinha legitimidade para contrariar toda a tradição historiográfica defendida pelos predecessores.

Na medida em que se aproximava o centenário da Revolução Farroupilha, os assuntos ligados à sua memória seguiam cada vez mais presentes nas sessões do IHGB. Rompia-se gradualmente a crosta de gelo e a aura de pudor com que se tratava do assunto. ${ }^{52}$ As controvérsias e as arestas a respeito do caráter dos heróis farrapos eram aparadas para além do debate historiográfico e político regional, marcando também sua presença no âmbito do IHGB. De toda forma, tal como se iniciara em 1921, seguia o processo de reabilitação das individualidades, mas não do caráter do movimento.

O fato de se festejar o centenário farroupilha no IHGB não constituía novidade, já que, como visto, ao longo dos anos iniciais do século $\mathrm{XX}$, as sessões celebrativas do Instituto tinham propiciado uma reabilitação da Guerra dos Farrapos no quadro das efemérides nacionais regularmente festejadas, como a Revolução Pernambucana o tinha sido, por exemplo, em $1917 .{ }^{53}$ Foi nessa ocasião, inclusive, que Homero Baptista fez a sua conferência sobre as revoluções brasileiras, incluindo a Farroupilha na continuidade da Pernambucana. Contudo, o que chama a atenção no caso do centenário farroupilha é que as comemorações começaram três anos antes, já em 1932, ano emblemático

\footnotetext{
${ }^{51} \mathrm{~A}$ perda da província Cisplatina representou prejuízos aos interesses econômicos daqueles que viriam a ser os líderes farrapos anos depois e foi apontada como parte das tensões que se acumulavam entre estes e os representantes políticos e militares designados pelo governo central. Ver, por exemplo, Cesar Augusto Barcellos Guazzelli, "O Rio Grande de São Pedro na primeira metade do século XIX: Estadosnações e regiões províncias no rio da Prata", In: Luiz Alberto Grijó et al., Capítulos de história do Rio Grande do Sul, Porto Alegre, Ed. UFRGS, 2004, p. 91-120. Além de Bento Manoel, também outros líderes como David Canabarro e Bento Gonçalves lutaram na Cisplatina.

${ }^{52}$ Ainda no ano de 1927, Eugênio Vilhena de Moraes escolhe como assunto de sua conferência "A surpresa de Porongos", episódio polêmico do final da Guerra dos Farrapos em que muitos combatentes negros das forças farroupilhas foram mortos e sobre o qual pesava a suspeita de uma combinação entre os adversários, neste caso, Caxias e Canabarro, para facilitar e acelerar o processo de paz. A conferência de Vilhena de Moraes não foi inteiramente transcrita na ata da sessão em que foi pronunciada, mas o relato do secretário a respeito de seu conteúdo é suficiente para se verificar a continuidade da reabilitação dos chefes farrapos. O ocorrido em Porongos teria sido uma surpresa e não uma traição, o que explicaria a grande quantidade de mortos em combate e isentaria Canabarro da suspeita de traição. RIHGB, t. 101, vol. 155, 1927, p. 259.

53Sobre as comemorações do centenário da Revolução de 1817, ver Lucia Maria Paschoal Guimarães, “Entre a monarquia e a república: a Revolução Pernambucana de 1817 e suas representações no Instituto Histórico e Geográfico Brasileiro", In: Mônica L. Lessa; Silvia C. P. de Brito Fonseca (orgs.), Entre a monarquia e a república: imprensa, pensamento político e historiografia (1822-1889), Rio de Janeiro, Ed. UERJ, 2008, p. 151-164.
} 
para as disputas simbólicas em torno do governo Vargas, ${ }^{54}$ e aconteceram nos dias 20 de setembro daquele e dos próximos anos, até $1935 .{ }^{55}$ A primeira coube a Souza Docca, que ocuparia mais uma vez a tribuna para falar a respeito daquele que consolidava como evento maior da história gaúcha. ${ }^{56}$ Desta feita, munido de outros documentos e interpretações, Souza Docca retoma a análise sobre um dos temas mais ambíguos em sua conferência em 1921: o caráter republicano da Revolução Farroupilha.

Neste ponto, é necessário matizar a noção de enquadramento que pode sugerir a imposição de uma determinada tradição. No caso do caráter republicano da Revolução Farroupilha, as demandas de ressemantização no início do século XX não buscavam a substituição de uma memória monárquica por outra republicana. Elas diziam respeito sobretudo ao estabelecimento de uma nova coerência entre as memórias históricas regional e nacional, que se construíam como republicanas desde fins do século XIX. ${ }^{57}$ Desde essa época, as lutas republicanas e federalistas no Rio Grande do Sul foram marcadas por um discurso antimonárquico, que, por vezes, se utilizava da distinção geográfica, econômica, ideológica e cultural da província sulina em relação às demais, como argumento para a demanda de autonomia. Conforme Ângela

\section{O caráter revolucionário do conflito, em suma, se configurava pela adesão coletiva a um ideal: a República federativa}

Alonso, o caso dos federalistas científicos gaúchos (agremiados no Clube Vinte de Setembro) e paulistas, distinguiu-se daqueles de outros grupos da geração de 1870, porque a contestação da ordem monárquica se deu pela reedificação das "velhas tradições democráticas" regionais, como a Revolução Farroupilha:

\footnotetext{
${ }^{54}$ Em 1932, a Revolução Constitucionalista de São Paulo representou um embate mais do que militar com o governo federal. Colocavam-se em cheque várias justificativas invocadas pelos defensores do "outubrismo" para legitimar a deposição de Washington Luís em 1930. Marco Cabral dos Santos; André Mota, São Paulo 1932: memória, mito e identidade, São Paulo, Alameda, 2010.

${ }^{55} \mathrm{Na}$ sessão de ordinária de 4 de junho de 1932, Pedro Calmon já fizera uma conferência sobre Giuseppe e Anita Garibaldi nas festividades garibaldinas que vinham se desenvolvendo na América e na Europa, às quais se associava o Instituto. Na festividade, esteve presente o embaixador italiano no Brasil. Anita e Garibaldi eram lidos na mesma chave que operava a reabilitação das individualidades que não englobava, ainda, o caráter do conflito. Segundo Afonso Celso, venerava-se principalmente a união de italianos e brasileiros verificada já nos casamentos da família real do século XIX. RIHGB, vol. 166, 1932, p. 644-669, em especial, 661 e 668.

${ }^{56} \mathrm{~A}$ conferência intitulava-se "Ideologia federativa na cruzada farroupilha", Idem, Ibidem, p. 703-732.

${ }^{57}$ Outras províncias, como Pernambuco, iniciaram antes o processo de integração da memória republicana regional com a nacional. Seja porque, cronologicamente, os centenários das revoluções pernambucanas de 1817 e 1824 ocorreram mais cedo, ou porque havia uma institucionalização mais efetiva da escrita da história naquele estado, em comparação com o Rio Grande do Sul (Pernambuco, assim como São Paulo, fundara seu Instituto Arqueológico Histórico e Geográfico ainda no século XIX e dispunha de uma articulação muito mais efetiva com o IHGB, contando com um número muito maior de membros na casa nacional).
} 
“Novos heróis e 'revoluções' ganharam obras e eventos de desagravo, no que os federalistas científicos gaúchos foram particularmente pródigos, erigindo heróis próprios, como Bento Gonçalves" ${ }^{58}$

Desta forma, Souza Docca parece retomar esse processo iniciado no século XIX, no campo da literatura, com o Parthenon Literário, passando pelo discurso político dos militantes republicanos e continuado por ele mesmo e pelos integrantes do IHGRS na década de 1920, no campo memorialístico e historiográfico, com a glorificação dos chefes farroupilhas. Entretanto, no início da década de 1930, esse processo de reabilitação da memória farroupilha se vê remetido ao imperativo da sua articulação com a memória nacional. A nova posição assumida pelo Rio Grande do Sul desde os anos 1910 na condução política nacional demandava, mais do que no contexto das reivindicações federalistas do século XIX, a sua inserção na tradição republicana nacional. As ideias republicanas presentes dentre os farrapos, que Souza Docca havia atribuído em 1921 a influências exógenas e mal digeridas no contexto sul-rio-grandense da década de 1830, agora apareciam como uma tendência natural, como um genuíno fruto da terra. O republicanismo, segundo o autor, não era a ideologia esposada pelas principais chefias farroupilhas, mas havia sido adotado por um grande número de agitadores, cuja atuação não era mais vista com a desconfiança demonstrada anteriormente. Em 1932, o historiador sul-rio-grandense considerava os agitadores republicanos de 1835 como homens verdadeiramente abnegados em torno de uma causa que souberam defender e difundir a ponto de obterem a adesão das principais lideranças e do povo. Desta forma, os líderes farrapos apareciam nesse momento como aqueles que haviam compreendido as necessidades da província e percebido a melhor solução para contemplar as diferenças entre as partes do Império: a república federativa. Deixavam de ser heróis para se tornarem os grandes homens da nação. ${ }^{59}$

A noção de república no contexto de crítica do liberalismo dos anos 1920, diferentemente do que propuseram Araripe e Assis Brasil em 1880, não se identificava com a de democracia, pois não enfatizava a consulta e a participação popular. Era definido por Souza Docca como liberdade e autonomia da administração provincial frente à do Império. Sob essa ótica, os farrapos teriam sido verdadeiramente republicanos, propugnando uma federação com outras províncias brasileiras. Sua volta ao seio do Império no final da guerra não representava desistência da luta pela República, mas sim abnegação patriótica dos líderes ante a ameaça externa que o ditador argentino Rosas representava para a integridade da nação brasileira naquele momento.

Souza Docca apresentava, desta forma, novos elementos no processo de enquadramento e reabilitação da memória farroupilha. A um só tempo, o

\footnotetext{
58Ângela Alonso, Ideias em movimento: a geração 1870 na crise do Brasil-Império, São Paulo, Paz e Terra, 2002, p. 292.

${ }^{59}$ Hartog e Dosse, ao discutirem a passagem das biografias antigas às modernas, ressaltam que os heróis antigos, vistos como semideuses, dariam lugar, no contexto da ascensão dos estados nacionais, aos grandes homens, cuja ação está ligada à promoção da coletividade. François Hartog, "Plutarque entre les Anciens et les Modernes". In: Plutarque, Vies parellèles, Paris, Gallimard, 2001, p. 9-49. François Dosse, O desafio biográfico: escrever uma vida, São Paulo, Edusp, 2009.
} 
movimento que manteve durante dez anos uma guerra contra o Império tornava-se não somente digno e glorioso, mas também patriótico e indispensável à integridade da nação! Após uma verdadeira operação de glorificação, nos anos precedentes, em relação às individualidades farroupilhas - que agora pairavam com suas auras de grandes homens, desprendidos e corajosos, acima das controvérsias ideológicas do conflito - , o próprio caráter do evento sofria uma releitura. A continuidade entre os ideais republicanos de 1835 e os de 1889 e o caráter brasileiro do movimento são explicitamente estabelecidos. ${ }^{60}$

Outro problema presente no discurso de Souza Docca é o que se refere à noção de revolução. Nesse momento, em que o governo Vargas fora recentemente ameaçado e vencera a "revolução" constitucionalista, há uma verdadeira disputa em torno do sentido desse conceito, da qual o texto de Docca não se isenta. ${ }^{61}$ Ele argumentava que, se o objetivo dos chefes tivesse sido apenas a deposição do governador, como enfatizara em 1921, o movimento deveria ser qualificado como revolta e não como uma verdadeira revolução. ${ }^{62}$ Desta forma, destacando o caráter republicano que o conflito acabara por tomar, Docca associava novamente a noção de revolução com a de República, mas enfatizando a adesão popular, agora positivada, ao contrário da forma pela qual a qualificara, em 1921, como propensão natural do povo à violência e à desordem. O caráter revolucionário do conflito, em suma, se configurava pela adesão coletiva a um ideal: a República federativa, que, além de operar como argumento contra a acusação de caudilhismo, mitigava o separatismo enquanto causa abraçada por parte do movimento. É essa a contraposição explícita que faz Souza Docca ao iniciar o subtítulo "Federação" de sua conferência. Para ele, somente os "separatistas" é que podiam negar a existência do ideal federativo dentre os farrapos. No discurso de 1932, "separatista" era, antes de tudo, aquele que interpretava de forma equivocada os elevados ideais federalistas, somente suplantados como marca moral do movimento, pelo patriotismo que supostamente impusera à consciência dos chefes farrapos a opção pela paz com os imperiais em prol da defesa da pátria, ameaçada por Rosas. A elevação desse gesto era colocada sob suspeita pela tese historiográfica do separatismo, que adquirira em seu discurso, no presente dos anos 1930, o estatuto de sujeito histórico:

O azinhavre do separatismo tentou manchar esse gesto de acrisolado civismo gaúcho, taxando-o de artifício, mas não o conseguiu, porque o sentimento de brasilidade dos rio-grandenses do sul, na constelação política de nossa Pátria, paira, como aquele cântico da musa inspirada de Guerra Junqueiro: "Tão límpido, tão alto, que parece que é a estrela do céu que está cantando".63

60R/HGB, vol. 166, 1932, p. 726

${ }^{6}$ Vavy P. Borges, Tenentismo e revolução brasileira, São Paulo, Brasiliense, 1992, p. 13-18. Segundo a autora, a denominação "Revolução de 1930" para o golpe que destituiu o presidente Washington Luís teria se fortalecido após a vitória de 1932 sobre a autoproclamada "Revolução Constitucionalista”, que seria considerada pelos vencedores como uma contrarrevolução.

${ }^{62}$ RIHGB, op cit., p. 704.

63/dem, Ibidem, p. 731-732. 
Entre a conferência de 1921 e a de 1932, que abria as longas comemorações do centenário farroupilha no IHGB, Souza Docca operava uma verdadeira síntese do heterogêneo, não apenas obedecendo aos imperativos do enquadramento da memória regional no âmbito da memória histórica nacional, mas, acima de tudo, conferindo a essa representação a coerência narrativa necessária à dimensão persuasiva que se desejava atingir. ${ }^{64} \mathrm{O}$ próprio autor demonstra ter se ocupado das contradições e inconsistências que as ações das lideranças farroupilhas traziam para a representação que elaborava, referindo-se a elas como: "as mutações, zigue-zagues, as dubiedades, certos atos que parecem esquisitos, contraditórios e às vezes até criminosos e indignos de certas individualidades" ${ }^{65} \mathrm{O}$ resultado foi a articulação da Guerra dos Farrapos à memória histórica nacional como um movimento revolucionário, republicano, federalista, brasileiro e patriótico.

\section{Considerações finais: o centenário e a constituição da Revolução Farroupilha como problema historiográfico da história nacional}

É importante ressaltar que a operação de salvamento e glorificação do passado farroupilha era precedida e acompanhada por outras iniciativas para além do recinto do IHGB. No Rio Grande do Sul, a memória do movimento era disputada em diferentes versões, não apenas no âmbito do instituto histórico estadual, como também nas páginas dos periódicos e nos comitês oficiais constituídos para as comemorações do centenário, destacando-se a tese do abrasileiramento da Revolução Farroupilha ${ }^{66} \mathrm{O}$ governo do estado, as prefeituras e o IHGRS associavam-se em comitês destinados à preparação do grande ano de 1935. Além da exposição estadual projetada pela comissão dos festejos e do congresso de história preparado pelo Instituto, o governo autorizou a publicação de uma grande obra historiográfica no ano de 1933. Os seis volumes d'A história da Grande Revolução, de Alfredo Varela, por via das relações entre a esfera governamental e a instituição de história, vieram a lume, registrando na página de rosto: "edição comemorativa do centenário, estampada sob os auspícios do Instituto Histórico e Geográfico do Rio Grande do Sul e a expensas do governo do Estado".

\footnotetext{
${ }^{64}$ Michel de Certeau, A escrita da história, Tradução de Maria de Lourdes Menezes, 2. ed., Rio de Janeiro, Forense Universitária, 2002, p. 96 e Paul Ricoeur, A memória, a história, o esquecimento, Campinas, Ed. Unicamp, 2007, p. 254. ${ }^{65}$ RIHGB, t. 166, 1932, p. 705.

${ }^{66}$ Há uma farta bibliografia sobre o abrasileiramento da Revolução Farroupilha - um empreendimento intelectual dos anos 1930, que tinha no IHGRS uma referência central, e que se empenhou em aproximar as origens, principais motivações e características do conflito de outras revoluções e problemas brasileiros, negando as influências platinas que ele possa ter sofrido. Dentre os trabalhos mais importantes, estão os de leda Gutfreind, A historiografia rio-grandense, 2. ed., Porto Alegre, UFRGS, 1998 e Marlene M. de Almeida, Introdução ao Estudo da Historiografia Sul-rio-grandense: inovações e recorrências do discurso oficial (1920-1935), Dissertação, Porto Alegre, IFCH-UFRGS, 1983. Outro importante trabalho, do antropólogo Ruben Oliven, também trata do assunto ao enfocar a tensa construção da identidade regional do Rio Grande do Sul, que oscila entre a integração e o isolamento. De acordo com Oliven, no Rio Grande do Sul, a ênfase na distinção de sua cultura e a promoção de ideias separatistas tem sido amplamente utilizada para reforçar os argumentos de seus representantes nas negociações políticas com a federação brasileira em momentos de crise econômica. Ruben George Oliven, A Parte e o Todo: a diversidade cultural no Brasil-Nação, Petrópolis, Vozes, 1992.
} 
Souza Docca colocou-se, então, na oposição à obra de Alfredo Varela, empenhando-se nas páginas do Jornal do Comércio, do Rio de Janeiro - onde ambos moravam naquela época - , em refutar a sua tese de que os farrapos tinham sido adeptos do separatismo em virtude de seu precário sentimento de brasilidade. O cenário da disputa simbólica em torno da memória farroupilha, desta forma, extrapola novamente o regional e o debate assumiu os contornos daquilo que é comumente qualificado como um "diálogo de surdos", pois Varela se dedicou a responder principalmente as objeções levantadas ao estilo de sua obra, enquanto Docca preocupava-se sobretudo com o problema do separatismo e da brasilidade da revolução. ${ }^{67}$ No IHGRS, a carta de um intelectual gaúcho que acompanhava a polêmica entre os historiadores demandava um posicionamento mais claro da Instituição, refutando as teses separatistas de Varela sobre os farrapos. ${ }^{68}$ Depois de longos anos instrumentalizada pelo discurso político e decantada na literatura regionalista, a reabilitação da memória farroupilha em estreita conexão com a escrita institucionalizada da história regional e nacional cobrava o seu preço.

O processo de conversão da Revolução Farroupilha, nas vésperas de seu centenário, simultaneamente em objeto de culto cívico nacional e objeto historiográfico, oscilava entre as demandas da memória e da história, provocando reações apaixonadas por parte dos intelectuais de quem pretensamente se esperava, cada vez mais, pronunciamentos repletos de referências eruditas, concatenadas com a tradição historiográfica nacional, no lugar de discursos políticos inflamados. Entretanto, uma vez respeitados os procedimentos "científicos" legitimados pelas instituições, os textos dos historiadores logo se prestavam ao uso político, como se pode verificar na continuidade das conferências comemorativas do centenário farroupilha. ${ }^{69}$

Basílio Magalhães, designado como responsável pela conferência comemorativa de 20 de setembro de 1934, não concordava integralmente com a versão patriótica do decênio glorioso, ancorando-se no adversário de Souza Docca. ${ }^{70}$ Os motivos para essa discordância referem-se mais aos problemas do presente do que aos do passado. Magalhães menciona um episódio que precedeu

\footnotetext{
${ }^{67}$ Sobre o estilo e a concepção de história em Varela, ver Jaisson Oliveira da Silva, A epopeia dos titãs do Pampa: historiografia e narrativa épica na História da Grande Revolução, de Alfredo Varella, Dissertação, Porto Alegre, PPGH - UFRGS, 2010. Sua intenção de escrever uma grande epopeia pode ser comparada ao que se fizera em São Paulo, desde o final do século XIX, em relação aos bandeirantes. Antônio Celso Ferreira, A epopeia bandeirante: letrados, instituições, invenção histórica (1870-1940), São Paulo, Ed. UNESP, 2002.

${ }^{68} \mathrm{~A}$ carta que Castilhos Goycochea escreveu ao secretário do IHGRS deu origem a uma comissão responsável por um parecer sobre a obra de Varela. A comissão, mesmo integrada por ferrenhos adversários da versão separatista de Varela, teve de ser branda nas suas conclusões, já que se tratava de um membro do IHGRS, amigo do interventor: limitou-se a dizer que o IHGRS não esposava de todas as teses ali veiculadas. RIHGRS, 40 trim., 1934, p. 268.

${ }^{69}$ Conforme Grijó, "Entre a barbárie e a civilização: os conflitos armados no período republicano”, In: Eduardo Santos Neumann; Luiz Alberto Grijó (orgs.), O continente em armas: uma história da guerra no sul do Brasil. Rio de Janeiro, Apicuri, 2010, p. 182-183, foi nessa época que se operou um verdadeiro processo civilizatório do estado sulino. Os homens deixavam a espada pela pena. O IHGB e o IHGRS desempenharam aqui um papel importante. RIHGRS, 4 O trim., 1934, p. 268.

70 Já na conferência de 1932. Docca se referia ao equívoco das interpretações veiculadas por Basílio de Magalhães, embasadas em Assis Brasil e Alfredo Varela, sobre o papel dos italianos (Zambeccari e Garibaldi) na difusão das ideias republicanas no período farroupilha. RIHGB, vol. 166, 1932, p. 716-717.
} 
a Revolução de 1930 em que ele, ocupando cargo representativo, opusera-se energicamente ao uso político que um de seus contendores fazia do passado farroupilha. ${ }^{71}$ Em seguida, argumenta que o separatismo não era necessariamente uma mácula e estava presente no Brasil, desde o século XVII. Mineiro de nascimento, opositor da Revolução de 1930 e autor de livros sobre o bandeirismo paulista, parecia se referir ao contexto recente do conflito paulista com o governo Vargas, pois ali se tinham verificado também manifestações de cunho separatista cujo objetivo era mobilizar a população para se engajar do lado de São Paulo. ${ }^{72}$ Após isso, afirmou a existência de separatismo dentre os farrapos, amparando-se também em outro historiador sul-rio-grandense, Aurelio Porto, confrade de Souza Docca no IHGRS, que pesquisava também o "Processo dos Farrapos" na capital federal. ${ }^{73}$

Entretanto, a disputa de memórias extrapolava a questão do separatismo e Magalhães buscava fragilizar a autoridade intelectual de Souza Docca, não se referindo uma única vez à sua conferência de 1932, ao contrário daqueles que vinham ocupando a tribuna do IHGB para falar sobre o assunto, desde então. Colocando-se no lugar de um historiador no presente, Magalhães rebaixava a patente historiográfica do tenente-coronel, ironizando a sua autoridade perante a de historiadores de renome como Alfredo Varela, Assis Brasil e Aurelio Porto: “Tratando-se de uma questão de tal relevo, a exigir detido exame e profunda meditação, como é que poderia eu atrever-me, simples e bisonho soldado raso, a divergir desses marechais das nossas letras, uns ainda felizmente vivos, e outros já viajeiros do além" ? ${ }^{74}$ Contudo, apesar da hostilidade contra Souza Docca, Magalhães, tal como Varela, não discordava da necessidade de reabilitação dos farrapos, especialmente dos chefes do movimento, na memória nacional, ratificando as patrióticas intenções da paz entre farrapos e imperiais. ${ }^{75}$ Divergiam sobre os motivos, mas não sobre a justiça da glorificação das lideranças farroupilhas; divergiam, na verdade, sobre os usos do passado no presente.

Para além deste testemunho, o sucesso da releitura do passado farroupilha e sua integração na memória nacional pode ser medido pelas declarações do presidente do IHGB em 1921 e 1932. Em 1921, após a conferência de Souza Docca, Afonso Celso se refere à Revolução Farroupilha como um conjunto de "graves acontecimentos", cuja "tentativa separatista" deveria ser

\footnotetext{
71“[...] não me era possível ouvir ali, numa impassibilidade de faquir em êxtase, heresias e desacertos concernentes a episódios máximos de nossa nacionalidade, explorados para fins subversivos. Protestei, corrigi, dilucidei, e isso quando já estava a fechar-se para mim, definitivamente, a tribuna daquela assembleia federal, e quando, vitoriosa a revolução de 1930, não mais dispunha eu de colunas livres de imprensa, para manter-me na liça em público". RIHGB, vol. 169, 1934, p. 381.

${ }^{72} \mathrm{Se}$, no Rio Grande do Sul, qualquer tipo de mobilização política envolvia o acionamento das heranças farroupilhas, em São Paulo, havia a epopeia bandeirante, que, no contexto da revolução constitucionalista, forneceu elementos para um discurso que beirou as raias do separatismo. Marco Cabral dos Santos; André Mota, São Paulo 1932: memória, mito e identidade, São Paulo, Alameda, 2010.

${ }^{73} \mathrm{O}$ Processo dos Farrapos, que se encontrava no Arquivo Nacional, foi copiado e tornou-se objeto de pesquisa de Souza Docca e Aurelio Porto na década de 1930, especialmente antes do centenário farroupilha. ${ }^{74}$ RIHGB, vol. 169, 1934, p. 385.

75/dem, Ibidem, p. 398.
} 


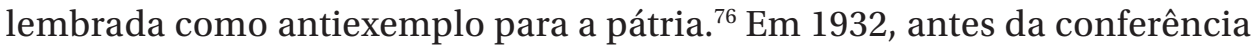
de Souza Docca, o presidente ainda se referia ao conflito como um "episódio doloroso da nossa história", ressalvando, entretanto, que do seu estudo resultavam "impressões desvanecedoras", como o

heroísmo manifestado por ambas as partes, o realce de grandes figuras, como Bento Gonçalves e de Caxias, o desfecho honroso da luta, e completa reintegração do Rio Grande do Sul na comunhão política do Brasil, ao coração do qual sempre esteve e sempre estará incorporado. ${ }^{77}$

Afonso Celso, sem intenção, revelava cada elemento da coerência narrativa construída por Souza Docca e boa parte dos integrantes do IHGRS, ocultando apenas sua eficaz estratégia de dupla inserção institucional que desempenhou papel fundamental na disputa pela memória farroupilha. A tese da brasilidade se fazia vitoriosa no coração da casa da história do Brasil. 